\title{
UNIVERSALS AND MATHEMATICAL LINGUISTICS
}

\author{
VI.D.Mazurov, vldmazurov@gmail.com, \\ E.Yu.Polyakova, ekaterina.y.polyakova@gmail.com \\ Ural Federal University named after the first President of Russia B.N. Yeltsin, \\ Ekaterinburg, Russian Federation
}

Universals (from Latin "universalis" - general) - general concepts - are a subject matter of logicians since the ancient times. The question of universals represents the eternal issues. The nature of universals was thoroughly studied the philosophers of the Middle Ages. In IX-XIV centuries the scholastics continued the discussion about the essence of universals: do they really exist or are they certain names? The supporters of realism claimed that universals really existed and preceded the emergence of singular objects. Nominalists (from the Latin word 'nomen' - name) defended the contrary view point.

In the article we emphasize the linguistic aspect. Mathematical linguistics develops methods of learning natural and formal languages. Linguistics, logic and mathematics are closely connected. Besides, there exists psycholinguistics as well. In our paper we consider current difficult sections: logic and linguistics of non-formalized and even non-formalizable concepts, the topic closely adjacent with the one discussed in the book by T.K. Kerimov of the same name. These sections broaden the opportunities of studying complex systems of logic and linguistics. As it was noted by the authors of "Mathematical linguistics" (R.G. Piotrovsky, K.B. Bektaev, A.A. Piotrovskaya) mathematics and a natural language represent semantic systems of information transfer. Moreover, there occurred a verbal analysis of mathematical problems solution.

Language universal, a feature common for all the languages, is a kind of generalization of the language concept. The existential assertion of universals gives the opportunity to formulate a more grounded theory and practice of linguistics. The language universal determination is based both on extrapolation and empirical matter.

Keywords: general concepts, mathematical linguistics, neural networks, mixtures.

\section{Introduction}

The ancient concept of universals as general concepts is still topical. The language is changing, the new terms are being coined but the problem of universals as such is not vanishing. This term is connected with many new important concepts, such as, for example, the problem of language description, that of name nature etc. Mathematical linguistics develops both a formal apparatus of language description and a semantic one. Structural linguistics is a linguistic discipline within the scope of which a language is considered in terms of its structure as a formal system.

\section{Overview}

We apply a proposed "principle of external classification" and that of recognition of the phenomena which have not been recognized so far. Thus, the problems of predicting technological properties of mixtures have been solved this way since 1970 at the Mathematical programming department in Institute of Mathematics and Mechanics of the Ural Branch of the Russian Academy of Sciences, including metal manufacturing simulation problems where raw materials simulation represents a difficult problem of recognition. The fact that raw materials for the metallurgical processes are a complex structure is taken into account in these models.

At present we are solving a problem of properties recognition of material mixtures on the basis of neural networks. At the Mathematical programming department the subject of mixing (of materials, technologies, algorithms) is traditional, for example, in mining industry, in metallurgy it is seen in charge mixtures property prediction. The articles on the issue were found in Bourbaki's [1]. Committee method applies algorithm mixing as well [2-3]. In general, the issue is related to collective decisions in operation research problems.

When modeling technical and economic problems, certain non-formalized concepts can occur, and this is when we apply identification methods based on neural networks [4]. 
We are considering the ancient problem of universals and general concepts on the basis of modern developments in algorithm theory and in mathematical linguistics. This issue is highly topical in its connection with the problem of factor and feature name in the problems of data and knowledge processing.

We also use the general nominalism principle when modelling unique objects in the sense that we consider singular reality as a single and exclusive one. Nominalism is an interpretation paradigm providing a semantic domination of a specific singularity over the abstraction of the general.

\section{Structuralism}

Structuralism is a set of holistic trends emerging first in the Humanities. It turned out that the first structuralists were Russian Eurasianists: N. Trubetskoy, R. Jakobson, P. Savitsky. Their researches refer to the 1920's - 1930's. First this trend emerged in the field of linguistics, N. Marr was opposing to this trend [5], F. de Saussure came up with another ideology and a bit earlier. From his point of view a language is a certain structure that does not depend on the objects it expresses. Saussure also specified the two sides of language elements exchange (e.g. words). He likened words to money: money is exchanged for material things on the one hand, and on the other hand, it is exchanged for some other sign units (money, securities). The same happens to words: on the one hand, there are links to references, on the other - there is an existence of words in the sign structure.

In this way Russian structuralism is connected with mathematical linguistics, Eurasianism, psychoanalysis. This is the Prague School of linguistics, established by the philosophers exiled from Russia.

No matter how strange it may be, even J. Stalin, "the main coryphaeus in all the sciences" with his research "Linguistic questions" has a relation to this topic. In the same way, N. Marr should be mentioned who is marked by his rich imagination: he considered language as a superstructure and he developed a theory of language stageness.

This material is found in P. Sériot's book "Structure and the whole", covering the intellectual sourced of structuralism in Central and East Europe [6].

C. Lévi-Strauss used a structural approach in ethnographic research [7].

In reality in its pure state structuralism is connected with the research of relation and operation algebra, in a certain sense this is an abstract algebra, not without reason mathematical structuralists are associated with N. Bourbaki. In the field of the Humanities C. Lévi-Strauss approached to this trend: he spoke of oppositions and correlations.

F. de Saussure states about a conscious object construction, this can be considered a compliance with nominalism; according to N. Trubetskoy an object initially exists as an organic integrity and it corresponds to the realism principle. F. de Saussure states that a language has nothing but differences.

Philosophical structuralism in France emerged in 1960's, becoming a fashionable trend and pushing existentialism aside [8-9].

In their very primitive form these approaches are implemented in the form of frequency analysis of words in texts. Actually it is connected with the notion of p-committees as such a system of elements where more than pth part of the elements of the system satisfies every predicate.

Structuralist approach enables to formalize the non-formalized, it is shown within the mathematical synthesis of choice and diagnostics.

Unconventional formation of nonintrinsic objects (connected with controversial dispatching systems) is possible on the basis of committee constructions introduced by us and formally studied which enable to generalize the concept of object existence.

\section{Russian structuralism and factor analysis}

When I got engaged into factor analysis, the factor name problem forced me to address to mathematical linguistics, and linguistics - to mathematical structuralism. All of this turned out very interesting for me. I had to find out how to evaluate the factor names objectively.

As it turned out, the principal trends in these fields are Eurasianism, Russian structuralism and Russian linguistics, though the forerunner of structuralism is F. de Saussure (1857-1913) [10]. Structural linguistics is a study of language as a system where all the elements are interconnected. F. de Saussure is a Swiss linguist who did the groundwork for semiotics (semiology) and structural linguistics. Semiology is a part of social psychology, it is a science of sign systems. Linguistics is a part of semiology. 


\section{Информатика и вычислительная техника}

Russian linguistics is rooted in European dispute about the limits between the natural and social sciences.

Russian philosophers and philologists exiled by L. Lenin from Russia moved to Europe. The Russian school - the Prague School of linguistics - was established in Prague. R. Jacobson, N. Trubetskoy, P. Savitsky and others started to work. The Russian structuralism connected to linguistics emerged.

Here it should be mentioned about N. Marr. A great number of questions arise but I will talk only about the most important. Marr Nicholas Yakovlevich (1864-1934), academician since 1912, Vicepresident of Academy of Sciences of The USSR, orientalist and specialist in Caucasian studies. The son of a Scottish father and a Georgian mother. Spoke many Caucasian and European languages. He is honored in Armenia and Georgia. He created "a new theory of the language" about Semitic and Kartvelian relations, developed Japhetic theory (Japhet is Noah's son). In every language N. Marr would find a Japhetic element. In 1926 he started to draw his theory close to Marxism. He demonstrated an unlimited imagination, stating that a language is a superstructure over the social and economic basis. During the Congress of the All-Union Communist party (Bolsheviks) in 1929 he made a speech on behalf of the scientists directly after Stalin. Many thought that in 1920 he was mentally sick. In 1950 his teaching was debunked.

In 1960's the French structuralism emerged (C. Lévi-Strauss and others).

There are two principal trends in mathematical linguistics: statistical analysis of texts and problem of translation from one language into another, the main tools are dictionaries.

The problem of factor names is also connected with that of translation. This field - the problem of translation - was managed by Alexey Andreevich Lyapunov. The quality of translation required the participation of philologists and linguists. Lyapunov invited Igor Alexandrovich Melchuk who revealed the necessity of deep dive into philology and also the fact that everything related to the problem of translation hinges on dictionary. This way, he noticed the impairment of Lyapunov's approach. Besides direct programming a text meaning analysis is needed as well. Nowadays Melchuk lives in Canada, he is the most prominent specialist in the problem of translation. He has developed the 'meaning-text' procedures necessary for translation problem.

He has also developed an explanatory combinatorial dictionary of the Russian language. It is of a special kind, the main component of language model in the 'meaning-text' theory.

Moreover, linguistic analysis includes the following parts:

Syntax-semantics-pragmatics.

To solve the problem of naming we suggest the following scheme:

Objects are $x \in X$, their names: $w(x)$. In general, we obtain a broadened object entry: $[x ; w(x)]$.

The neighborhood of the object is syntactic and semantic.

Hence, the factor name is in the intersection of neighborhoods, with the initial object removed from the close objects.

The Russian structuralism in 1980's was the structuralism of mathematicians: application package structure was studied and I participated in it.

Modern application packages are complex software systems with a multitude of functions.

\section{Data and knowledge processing}

In 1960 N. Bourbaki in his treatise "Elements of mathematics" [11] announced about his program of examination of all or almost all mathematics on the basis of the set theory. Mathematical objects are considered as sets, provided with this or that structure. A multivolume edition by N. Bourbaki "Elements of mathematics" is supplemented with the works of N. Bourbaki's seminar, the main goal is to make the most prominent mathematical achievements accessible for practitioners. Methodological basis is structuralism.

In economics structuralism appears in the works on mathematical economics e.g. the works by J.von Neumann on games theory and capital growth model in diversified economy [12], the work by $\mathrm{K}$. Arrow on collective methods of decision making and his impossibility theorem of agreement of several criteria of effective solution choice [13]. This theorem is supplemented with the Mazurov's theorem [14] of the possibility of collective diagnostics of objects and situations. As it turned out, choice and diagnostics are fundamentally different problems. Diagnostics is easier in some way but for example psychological diagnostics requires application of rigorously substantiated mathematical methods. 
In metal production economy both technology mixtures and material mixtures - charge mixtures are applied. The same refers both to composite materials production and powder metallurgy.

\section{Choice and agreement}

Many problems of effective choice of technology turn out to be incompatible and non-formalized. Moreover, they can also be non-formalizable. It is often necessary to choose the effective technology. In this case we find maximum installed joint subproblems and minimum installed disjoint ones. In these situations no ordinary decision can be found but we broaden the notions of compatibility, introducing generalization of decision concept, e.g. introducing the decision cycles of maximum joint subsystems of initial condition system. In this case we apply synthesis and analysis of artificial neural networks (ANN).

ANN is a mathematical model of a natural system of formal neurons for data and knowledge processing. It has a basic difference from ordinary algorithms, there an input data flow plays a role of a programmer. The connectionism principle is implemented in this model.

There is also a semantic approach to the problem of factor naming through words neighbourhood description, where all the words close in meaning are included.

The sets named in the process of nomination have a higher status than those unnamed.

In the ancient times a name was considered to be mystically connected to its owner, to reflect his/her character and even destiny. Here even unnamed sets occur.

One of the examples of unnamed sets was specially devised by Borges.

Let $\mathrm{W}$ be a word set. We use a direct product

$W \times R^{n}$,

working with the elements from this production.

The proposed method (we specify it as FM-method (factor-method) applies both metrics in the word space and other linguistic models. It involves the following.

Let there be given: table $\mathrm{A}=$ objects/features as well as the names of the objects and features. It is required to find:

Aggregative features - feature factors - and their names (direct problem);

Aggregative objects - object factor - and their names (dual problem);

Matrix FA: object factors/feature factors.

We use: interrelation of direct and dual problems.

To determine the factors we use taxonomy (cluster analysis).

To determine the names we apply mathematical linguistics.

It is required to compare:

- a direct problem with a dual one;

- F-method with FS method, where FS is a method of statistical factor analysis, FM - modified method;

- FM-method with the method of principal components.

To determine the factors, taxonomy is applied. Taxon involves features and their names. We build names neighborhoods and in their intersection we determine the factor name.

To determine objective factor names, mathematical linguistics is applied. The statement of the problem: a long word composed of feature names.

Example: technology aggregation in the problems of linear programming (LP). Search of factors is the identification of technology aggregation names when aggregating LP problem statement.

In particular in LP problem the statement is as follows:

$\sum v_{i} x_{i} \leq b, x_{i}$ is intensity of $v_{i}$ technology application, $x_{i} \geq 0$.

Here $v_{i}$ - vector is a column of resources cost per unit. When aggregating we obtain a vector - column $v \sim i$. Technology names are specified. Technology aggregation names are found by means of our factor naming technology.

\section{Conclusion}

The concept of universals we use in data and knowledge processes are considered in this article. The factor analysis and structuralism are applied to such processes. 


\title{
Информатика и вычислительная техника
}

\section{References}

1. Attouch H. Homogénéisation. Séminaire N. Bourbaki, 1987-1988, vol. 30, talk no. 686, pp. 7-30. Available at: http://www.numdam.org/item?id=SB_1987-1988 $30 \quad 7 \quad 0$

2. Mazurov Vl. D. Metod komitetov v zadachakh klassifikatsii $i$ optimizatsii. [Method of Committees in Tasks of Classification and Optimization]. Moscow, Nauka Publ., 1990. 248 p.

3. Mazurov V.D., Hachay M.Yu. [Parallel Calculations and Committee Designs]. Automatic Equipment and Telemechanics, 2007, no. 5, pp. 182-192. (in Russ.)

4. Tsypkin Ya.Z. Neyronnye seti: istoriya razvitiya teorii [Neural Networks: History of Development of the Theory]. Moscow, Radiotekhnika Publ., 2001. 840 p.

5. Marr N.Ya. Izbrannye raboty. Tom 4. Osnovnye voprosy istorii yazyka [Chosen Works. Volume 4. Main Questions of History of Language]. Leningrad, GSEI Publ., 1937. 328 p.

6. Serio P. Struktura i tselostnost' [Structure and Integrity]. Moscow, Yazyki slavyanskoy kul'tury Publ., 2001. 360 p.

7. Levi-Stross K. Pechal'nye tropiki [Sad Tropics]. Moscow, Mir Publ., 1984. 220 p.

8. Piazhe Zh. Izbrannye psihologicheskie trudy [Chosen Psychological Works]. Transl. from French. Moscow, Prosveschenie Publ., 1969. 659 p.

9. Bogomolov A.S. Sovremennaya burzhuaznaya filosofiya [Modern Bourgeois Philosophy]. Moscow, Vysshaya shkola Publ., 1978. 582 p.

10. Gumilev L. N. Ritmy Evrazii. Epokhi i tsivilizatsii [Rhythms of Eurasia. Eras and Civilizations]. Moscow, Panteya Publ., 1993. 575 p.

11. Burbaki N. Nachala matematiki. Ch. 1: Osnovnye struktury analiza. Kn. 1. Teoriya mnozhestv [Beginnings of Mathematics. Part 1: Main Structures of the Analysis. Book 1: Theory of Sets]. Moscow, Mir Publ., 1965. 455 p.

12. Neyman D., Morgenshtern O. Teoriya igr i ekonomicheskoe povedenie [Game Theory and Economic Behavior]. Moscow, Nauka Publ., 1970. 708 p.

13. Errou K. Kollektivnyy vybor $i$ individual'nye tsennosti [Collective Choice and Individual Values]. Moscow, GU VShE Publ., 2004. 201 p.

14. Enyukov I. S. Faktornyy, diskriminantnyy i klasternyy analiz [Factorial, Discriminant and Cluster Analysis]. Moscow, Finance and Statistics Publ., 1989. 215 p.

Received 20 March 2018

УДК 004.021

DOI: $10.14529 /$ ctcr180205

\section{УНИВЕРСАЛИИ И МАТЕМАТИЧЕСКАЯ ЛИНГВИСТИКА}

\author{
Вл.Д. Мазуров, Е.Ю. Полякова \\ Уральский фредеральный университет им. первого Президента России Б.Н. Ельцина, \\ г. Екатеринбург, Россия
}

\begin{abstract}
Универсалии (от латинского universalis - общий) - общие понятия - предмет изучения логиков с древнейших времён. Вопрос об универсалиях относится к разряду вечных проблем. Особенно интенсивно природа универсалий изучалась философами Средневековья. В IX-XIV веках продолжалась дискуссия среди схоластов о сущности универсалий: существуют ли они реально или это только некоторые наименования? Сторонники реализма утверждали, что универсалии реально существуют и предшествуют возникновению единичных объектов. Номиналисты (от латинского nomen - имя) отстаивали противоположную точку зрения.

В данной статье мы делаем акцент на лингвистике. Математическая лингвистика разрабатывает методы изучения естественных и формальных языков. Лингвистика, логика и математика тесно связаны. Кроме того, существует ещё психолингвистика. В наших работах мы рассматриваем современные трудные разделы: логику и лингвистику неформализованных и даже неформализуемых понятий. К этой теме близка тема неразрешимости, обсуждаемая в одноименной книге Т.К. Керимова. Эти разделы расширяют возможности изучения сложных
\end{abstract}


систем логики и лингвистики. Как заметили авторы книги «Математическая лингвистика» (Р.Г. Пиотровский, К.Б. Бектаев, А.А. Пиотровская), математика и естественный язык суть семантические системы передачи информации. Более того, возник вербальный анализ решений математических задач.

Языковая универсалия - свойство, присущее всем языкам - некоторое обобщение понятия о языке. Экзистенциальное утверждение об универсалиях даёт возможность более обоснованной теории и практики лингвистики. Установление языковой универсалии основано и на экстраполяции, и на эмпирическом материале.

Ключевые слова: общие понятия, математическая лингвистика, нейронные сети, смеси.

\section{Лumepamypa}

1. Attouch, H. Homogénéisation / H. Attouch // Séminaire N. Bourbaki. - 1987-1988. - Vol. 30, talk no. 686. - P. 7-30. - http://www.numdam.org/item?id =SB_1987-1988_30_7_0

2. Мазуров, Вл.Д. Метод комитетов в задачах классификаџии и оптимизаџии / Вл.Д. Мазуров. - М.: Наука, 1990. - 248 с.

3. Мазуров, В.Д. Параллельные вычисления и комитетные конструкции / В.Д. Мазуров, М.Ю. Хачай // Автоматика и телемеханика. - 2007. - № 5. - С. 182-192.

4. Цыпкин, Я.3. Нейронные сети: история развития теории / Я.3. Цыпкин. - М.: Радиотехника, 2001. $-840 \mathrm{c}$.

5. Марр, Н.Я. Избранные работы. Т. 4: Основные вопросы истории языка / Н.Я. Марр. - Л.: ГСЭИ, 1937. $-328 c$. $360 \mathrm{c.}$

6. Серио, П. Структура и целостность / П. Серио. - М.: Языки славянской культуры, 2001. -

7. Леви-Стросс, К. Печальные тропики / К. Леви-Стросс. - М.: Мир, 1984. - 220 с.

8. Пиаже, Ж. Избранные психологические труды: пер. с фр. / Ж. Пиаже. - М.: Просвещение, 1969. $-659 c$.

9. Богомолов, А.С. Современная буржуазная философия / А.С. Богомолов. - М.: Высшая школа, 1978. $-582 \mathrm{c}$.

10. Гумилев, Л.Н. Ритмы Евразии. Эпохи и цивилизации / Л.Н. Гумилев. - М.: Пантея, 1993. - 575 с.

11. Бурбаки Н. Начала математики. Ч. 1: Основные структуры анализа. Кн. 1: Теория множеств / Н. Бурбаки. - М.: Мир, 1965. -455 с.

12. Нейман, Д. Теория игр и экономическое поведение / Д. Нейман, О. Моргенштерн. - М.: Наука, 1970. - 708 c.

13. Эрроу, К. Коллективный выбор и индивидуальные ценности / К. Эрроу. - М.: ГУ ВШЭ, 2004. $-201 \mathrm{c}$.

14. Енюков, И.С. Факторный, дискриминантный и кластерный анализ / И.С. Енюков. - М.: Финансы и статистика, 1989. - 215 c.

Мазуров Владимир Данилович, д-р физ.-мат. наук, профессор, кафедра эконометрики и статистики Высшей школы экономики и менеджмента, Уральский федеральный университет им. первого Президента России Б.Н. Ельцина, г. Екатеринбург; vldmazurov@gmail.com.

Полякова Екатерина Юрьевна, старший преподаватель, кафедра издательского дела Уральского гуманитарного института, Уральский федеральный университет им. первого Президента России Б.Н. Ельцина, г. Екатеринбург; ekaterina.y.polyakova@gmail.com.

Поступила в редакцию 20 марта 2018 г.

\section{ОБРАЗЕЦ ЦИТИРОВАНИЯ}

Mazurov, V1.D. Universals and Mathematical Linguistics / Vl.D. Mazurov, E.Yu. Polyakova // Вестник ЮУрГУ. Серия «Компьютерные технологии, управление, радиоэлектроника». - 2018. - Т. 18, № 2. C. 54-59. DOI: $10.14529 /$ ctcr 180205

\section{FOR CITATION}

Mazurov Vl.D., Polyakova E.Yu. Universals and Mathematical Linguistics. Bulletin of the South Ural State University. Ser. Computer Technologies, Automatic Control, Radio Electronics, 2018, vol. 18, no. 2, pp. 54-59. DOI: $10.14529 / \mathrm{ctcr} 180205$ 